\title{
AN ANALYSIS OF THE ABO BLOOD-GROUP RECORDS OF THE NORTH OF ENGLAND
}

\author{
J. A. FRASER ROBERTS \\ Burden Mental Research Department, Stoke Park Colony, Bristol \\ and \\ Department of Medical Statistics and Epidemiology, London School of \\ Hygiene and Tropical Medicine
}

Received 14.ii.53

\section{INTRODUCTION}

THE very extensive records of the National Blood Transfusion Service have been used for a number of surveys in various parts of the British Isles. These surveys have varied greatly in scale and in the amount of detail included. Only a relatively small part, however, of the information available has actually been utilised and it seemed desirable, as a matter of some urgency, (i) to investigate systematically what use could be made of the present accumulation of particulars of donors' groupings, (ii) to search for possible difficulties and sources of error that might make their use dangerous, (iii) to discover economical ways of carrying out the analyses, and (iv) to suggest additional items of information of potential value that might be incorporated without too much practical difficulty. Apart from these questions of technique, it is desirable to discover how fine an analysis is likely to prove profitable. Should it be found, for example, that there is little variation in gene frequencies within large urban areas, then relatively modest samples would suffice. If, on the other hand, such areas showed real variations, then it would be worth while carrying out much more detailed counts. The broad outlines of the variation, particularly of genes $\mathrm{O}$ and $\mathrm{A}$, are known. But, underlying these, are there smaller local variations from place to place? This was not known. With these considerations in mind, Dr C. D. Darlington took the initiative in calling together a group of interested workers consisting of Dr W. d'A. Maycock, Dr A. E. Mourant, Dr R. R. Race and myself, and the Nuffield Foundation generously provided a grant which enabled the work to be carried out.

The main project, it was decided, should be a pilot survey, carried out in one of the Regions of the National Blood Transfusion Service. The Region selected was that based upon Newcastle-upon-Tyne and comprising the counties of Northumberland, Durham, Cumberland and Westmorland, with the northern part of the North Riding of Yorkshire. The authorities of the Region very kindly offered to make the cards available in batches for copying and have taken 
throughout a great amount of trouble in helping with the complicated arrangements that proved necessary. It was known that the records of this R gion were likely to be complete, in particular that the cards of resigned donors removed from the panel had been maintained since the beginning of the Service. Some previous surveys, for example my own in south-western England (1948), have included records of donors who had been provisionally grouped and added to the panel at the time of registration. This procedure makes a certain proportion of grouping errors inevitable and it is by no means certain that the errors will be independent of the location of the centres at which the preliminary grouping is carried out. Hence fine geographical subdivision, or a comparison of rural versus urban areas, are both unsafe. In the present material, donors were not added to the panel until they had made the first donation of blood, so that grouping errors were minimised and such as may remain are likely to be quite independent of geographical location. This makes it possible to sub-divide the material in any way desired.

\section{MATERIAL AND TECHNIQUE}

(i) General

The record comprised cards, one for each donor, there being, as is usual, no duplicates. Hence it was arranged that batches of cards should be sent to the London School of Hygiene and Tropical Medicine as they could be spared. The relevant particulars for each donor were copied on to a Powers-Samas punched card. When each batch was received the first step was to stamp a serial number on each original card, the serial number being subsequently copied on the corresponding punched card. This ensured that all cards were duly received and eliminated the risk that cards might be sent in twice. It also made it possible to resort the original cards before returning them into the order in which they were received.

A number of panels, maintained separately, referred to bodies of non-local donors, chiefly those at large Service establishments. These donors were not included in the count. One special panel was that of the Ministry of National Insurance ; these donors were included and a special indication was punched on the Powers card.

With one exception, the area code number, which is dealt with in the next section, the particulars to be copied were so simple that coding slips were unnecessary, the punched cards being prepared directly from the originals. The particulars copied, apart from area, were as follows :-

I. Serial number, as already mentioned.

2. Live or resigned panel. 
3. Family name, which was punched in full.

4. Sex and marital status, under the headings : man ; married woman ; single woman ; woman, marital status not recorded; sex not recorded.

5. ABO blood-group.

6. Rhesus positive or negative (when recorded).

The ages of donors were seldom recorded and so are not dealt with in this paper.

\section{(ii) Classification by area}

This was much the most difficult and time-consuming part of the task. The panels in which the original cards were maintained were much too large to be used. Moreover, for the practical purpose of bleeding donors often attend a centre near their place of work rather than their home, which, it had been decided, must be the basis of classification. Accordingly, every card had to be examined for home address.

The first principle in making the classification by area was to make the sub-division as fine as possible. Minimum size in number of donors was determined by the comparisons to be made. These were :-

I. The ratio $\mathrm{A} /(\mathrm{O}+\mathrm{A})$, originally used by Fisher and Taylor (1940). The variations in the proportions of genes $\mathrm{O}$ and $\mathrm{A}$ are largely reciprocal, so this comparison is a particularly useful one.

2. The ratio $(B+A B) /(O+A+B+A B)$, which is sufficient for an analysis of fluctuations in the frequency of gene $\mathrm{B}$.

It will be realised that with a very large number of areas to analyse and compare the convenience of examining heterogeneity by means of two simple $2 \times \mathrm{N}$ comparisons is very great. For the first comparison the minimum number of donors needed in each area is about 20; for the second about 70. So 20 was fixed as the minimum number; for making the second comparison the smaller areas would then have to be added together as was necessary in order to secure a minimum of 7 .

The next principle adopted was to keep separate as far as possible individual towns, parts of towns and villages. The largest city, Newcastle-upon-Tyne, was already divided into 4 separate panels; Gateshead, south of the river, providing a fifth. Where a definite district in a large city or town could be identified by a name in the address this was kept separate. In consequence certain larger towns and particularly the divisions of Newcastle tended to be to some extent residual areas left after identifiable districts within them or adjoining them had been counted separately. The addition of towns 
and villages to rural areas was avoided as far as possible; instead rural areas were, when it was practicable, added to each other. In forming the geographically larger rural and semi-rural areas, attention was paid to the features, such as valleys, roads and railways, that might be expected to facilitate communication.

When a batch of cards was received and the serial numbers had been stamped it was sorted as finely as possible by home address, the places being identified with the help of a set of one-inch Ordnance Survey Maps and Bartholomew's Gazetteer of the British Isles. A card index of every named locality, with map references, was built up as the work proceeded and proved very useful. The batches of cards were received, as they could be spared, more or less indiscriminately from centres all over the area. Panels overlap, and, furthermore, live and resigned panels were usually received separately. Thus at no stage could the material be reviewed as a whole and at times a good deal of guessing had to be practised. Area numbers had to be allotted and punched for considerably fewer than 20 donors in the anticipation that subsequent batches would make up the number. In individual instances single cards would be received from areas not yet dealt with (usually referring to donors working relatively far away from their homes); such cards were punched omitting the area code number and a slip was attached giving the full address, the punched card being then kept in a deferred file until cards were received from the area concerried. Not unnaturally, when the count was finished, a number of areas were found not to have attained the minimum number; these were added to each other or to adjacent areas as proved most convenient. On the other hand, the guess was sometimes a poor one in that a single code number was allotted to an unnecessarily large area, which, it was subsequently found, could have been sub-divided. Nor was it found when the work was completed that the boundaries of some of the scattered areas had been happily drawn.

A few donors lived over the Border in Scotland; they were omitted from the count. Similarly, a very few donors lived south of the southern boundary of the Region and they too have been omitted.

When the copying was finished and the cards were counted, it was found that the total number of donors was 54,579, divided into $32 \mathrm{I}$ areas, each containing at least 20 . The largest single area comprised 3260 . Of the $32 \mathrm{I}$ areas, I97, comprising all but some 8000 donors, were single towns, parts of towns, or villages; the remaining I 24 areas covered more than single towns or villages; sometimes indeed, in the more sparsely populated rural areas, considerable tracts of country. It will be seen, therefore, that the intention of keeping towns and villages separate as far as possible was largely realised, when considered in terns of donors. 


\section{(iii) The progressive addition of the areas into larger aggregates}

As already mentioned, while the $32 \mathrm{r}$ original separate coded areas were large anough for examining fluctuations in the ratio $\mathrm{A} /(\mathrm{O}+\mathrm{A})$, many fell short of the minimum number of 70 required for the investigation of fluctuations in the $\mathrm{B}$ ratio and so areas containing less than this number had to be added together. The principles observed in doing this and in all subsequent additions were the same as before, namely, to keep single towns, parts of towns and villages separate as far as possible and to follow natural and other features in adding other areas. Everything was done by inspection of the one-inch maps (on which the areas had been marked out). Needless to say, neither at this stage, nor at any other, was any regard paid to the proportions of donors belonging to the various groups, the additions being determined solely by geographical considerations. Naturally, the adding did not always prove as convenient as if the areas had originally been selected with the number 70 in mind. For example, it would happen that the only area to which a very small area could be added already contained more than 70 donors; or three areas all just under 70 would have to be combined. When the additions had all been made it was found that the number of areas at this second stage had been reduced to 196 .

An observation made at this stage was helpful in determining further procedure. The ratio $\mathrm{A} /(\mathrm{O}+\mathrm{A})$ was highly heterogeneous as between the 321 areas. When the additions had been made to give the 196 areas, it was noted that all the significant $\mathrm{A}: \mathrm{O}$ heterogeneity lay between the 196 areas and none within them. This suggested that the process of addition should be continued. There was now no factor in the analysis which determined any particular minimum size, so the figure of 300 donors was arbitrarily chosen as one that would roughly halve the number of areas. The number of areas was now reduced to 9o. Once again it was found that all the significant $\mathrm{A}: \mathrm{O}$ heterogeneity lay between the 90 areas. The effect on the ratio $(B+A B) /(O+A+B+A B)$ could also be investigated at this stage. At the original (for the B comparison) stage of 196 areas the ratio was highly heterogeneous ; but just as with the $\mathrm{O}: \mathrm{A}$ ratio, all this heterogeneity lay between the 9o aggregates of minimum number 300 .

Still further addition was indicated. The minimum size had to be 600 , as it was clear that at the stage now reached the areas of 3 oo could usually only be reasonably added in pairs. The number of areas was now reduced to $5^{2}$ and once again, for both comparisons, all the significant heterogeneity lay between the $5^{2}$ areas. As before, addition in pairs had to be the basis of the next step, the new total being 29 areas with a minimum of 1200 donors in each. It was now found that the process of addition had been carried too far. In respect 
of both ratios, the reduction to 29 areas left significant heterogeneity within those areas.

The results are shown in table I and are quite unequivocal. Starting with very small areas, in terms of numbers of donors, it is possible to go on adding adjacent areas, purely geographically, up to minimum aggregates of 600 donors. The aggregates are homogeneous within themselves and all the heterogeneity, both of the

TABLE I

Effect on heterogeneity of progressive addition of the 321 areas into larger aggregates

\begin{tabular}{|c|c|c|c|c|c|c|c|c|}
\hline \multirow{2}{*}{$\begin{array}{c}\text { Minimum } \\
\text { donors }\end{array}$} & \multirow{2}{*}{ D. of $F$. } & \multirow{2}{*}{$\begin{array}{c}\text { D. of } F . \\
\text { diffs. }\end{array}$} & \multicolumn{3}{|c|}{$\mathrm{A} /(\mathrm{O}+\mathrm{A})$} & \multicolumn{3}{|c|}{$(\mathrm{B}+\mathrm{AB}) /(\mathrm{O}+\mathrm{A}+\mathrm{B}+\mathrm{AB})$} \\
\hline & & & $\chi^{2}$ & $\chi^{2}$ diffs. & $\mathbf{P}$ & $\chi^{2}$ & $\chi^{2}$ diffs. & $\mathbf{P}$ \\
\hline $\begin{array}{r}20 \\
70 \\
300 \\
600 \\
\times 200\end{array}$ & $\begin{array}{r}320 \\
195 \\
89 \\
51 \\
28\end{array}$ & $\begin{array}{r}\mathrm{I} 25 \\
\mathrm{I} 06 \\
38 \\
23\end{array}$ & $\begin{array}{r}388.63 \\
252.41 \\
158.44 \\
118.06 \\
82.23\end{array}$ & $\begin{array}{c}\mathrm{r} 36 \cdot 22 \\
93 \cdot 97 \\
40 \cdot 3^{8} \\
35.83\end{array}$ & $\begin{array}{l}0.23 \\
0.79 \\
0.37 \\
0.043\end{array}$ & $\begin{array}{c}\ldots \\
262 \cdot 18 \\
149 \cdot 20 \\
I 11 \cdot 69 \\
7 r \cdot 14\end{array}$ & $\begin{array}{c}\ldots \\
\text { I } 12.98 \\
37.51 \\
40.55\end{array}$ & $\begin{array}{c}\cdots \\
0.31 \\
0.50 \\
0.013\end{array}$ \\
\hline
\end{tabular}

Summary

\begin{tabular}{|c|c|c|c|c|c|c|c|}
\hline \multirow{2}{*}{ Variation } & & \multicolumn{3}{|c|}{$\mathrm{A} /(\mathrm{O}+\mathrm{A})$} & \multicolumn{3}{|c|}{$(\mathrm{B}+\mathrm{AB}) /(\mathrm{O}+\mathrm{A}+\mathrm{B}+\mathrm{AB})$} \\
\hline & & D. of $\mathrm{F}$. & $\chi^{2}$ & $\mathbf{P}$ & D. of $F$. & $\chi^{2}$ & $\mathbf{P}$ \\
\hline Between $5^{2}$ areas & . & $5^{I}$ & 118.06 & $<0.0001$ & $5^{I}$ & $111 \cdot 69$ & $<0.0001$ \\
\hline Within 52 areas & . & 269 & $270 \cdot 57$ & $0 \cdot 46$ & I 44 & $150 \cdot 49$ & 0.34 \\
\hline
\end{tabular}

Note.-As the results are so clear it is unnecessary to recalculate the values of $\chi^{2}$ using adjusted divisors, $p q$, and divisors derived from the totals are used throughout.

ratio $\mathrm{A} /(\mathrm{O}+\mathrm{A})$ and of $(\mathrm{B}+\mathrm{AB}) /(\mathrm{O}+\mathrm{A}+\mathrm{B}+\mathrm{AB})$, lies between them. But the process cannot be carried further. Areas with a minimum number of donors of $\mathrm{I} 200$ are significantly heterogeneous within themselves in respect of both ratios.

Rough estimates may be attempted of what these numbers of donors mean in tes ms of total population. Taking the four counties and the northern part of the North Riding as a whole, and quoting figures to the nearest thousand throughout, the Registrar-General's estimate of total population was $2,834,000$ in $193^{8}$ and $2,836,000$ in 
1947, giving a mean of $2,835,000$. Dividing this figure by 52 , the number of areas that can reasonably be formed by progressive addition, the result is 55,000 ; division by 29 , the number of the larger areas that cannot be so formed, gives 98,0oo. Alternatively, one can estimate the total population corresponding to the minimum number of donors, that is, 600 and I200. The result is 31,000 and 62,000 respectively. As in any transfusion service, the region is covered with very variable degrees of thoroughness, the main factor being that it is economical to concentrate on the larger centres of population. Bearing this weighting in mind, it may be concluded that smaller areas can be progressively added, without introducing heterogeneity within themselves up to a point which corresponds very roughly to a total population size of the order of 50,000 .

\section{(iv) The gene frequencies and Fisher's test for group proportions in the 52 areas}

The basic data are presented in table 2. As others with particular anthropological, historical or geographical hypotheses to test might like to have more detail and so be enabled to add areas differently, the totals and the group percentages (from which the original numbers can be reconstructed) are shown separately for the penultimate stage of 90 areas.

The gene frequencies and the $\chi^{2}$ for Fisher's test for reasonableness of group proportions (Dobson and Ikin, 1946) are shown for the larger aggregates, comprising 52 areas. The results of the test can only be considered very satisfactory. All large bodies of data show a deficiency of group $\mathrm{AB}$; and the amount of the deficiency seems to be related to the care with which the grouping has been done and clerking errors avoided. Doubtless some at least of the larger deficiencies shown in some samples is to be attributed to such errors as some $\mathrm{A}_{2} \mathrm{~B}$ donors being wrongly assigned to group $\mathrm{B}$. But even with the most careful precautions, there are apparently always, or almost always, too few AB's. Thus in Dobson and Ikin's enormous and very accurately grouped sample of rgo,ooo the deficiency is 84, which does not, however, attain the level of significance. It is satisfactory that in the present relatively large sample, the deficiency in the total is no more than 87 , giving a non-significant $\chi^{2}$. The $\chi^{2}$ 's for the $5^{2}$ individual areas are even more satisfactory. There is one highly significant figure of $7 \cdot 6$ and one significant figure of $4 \cdot 7$, which seems very reasonable with 52 observations. In fact, the $5^{2} \chi^{2}$ s have a distribution which is remarkably close to theoretical expectation. As far, then, as one test (with a single degree of freedom) can be taken to indicate a satisfactory body of data, the records of this northern region of England give no indication of anything suspicious. 
TABLE 2

Four northern counties of England, with part of North Riding of Torkshire. Numbers and group frequencies for 90 areas, with gene frequencies and Fisher's $\chi^{2}$ for the 52 larger aggregates.

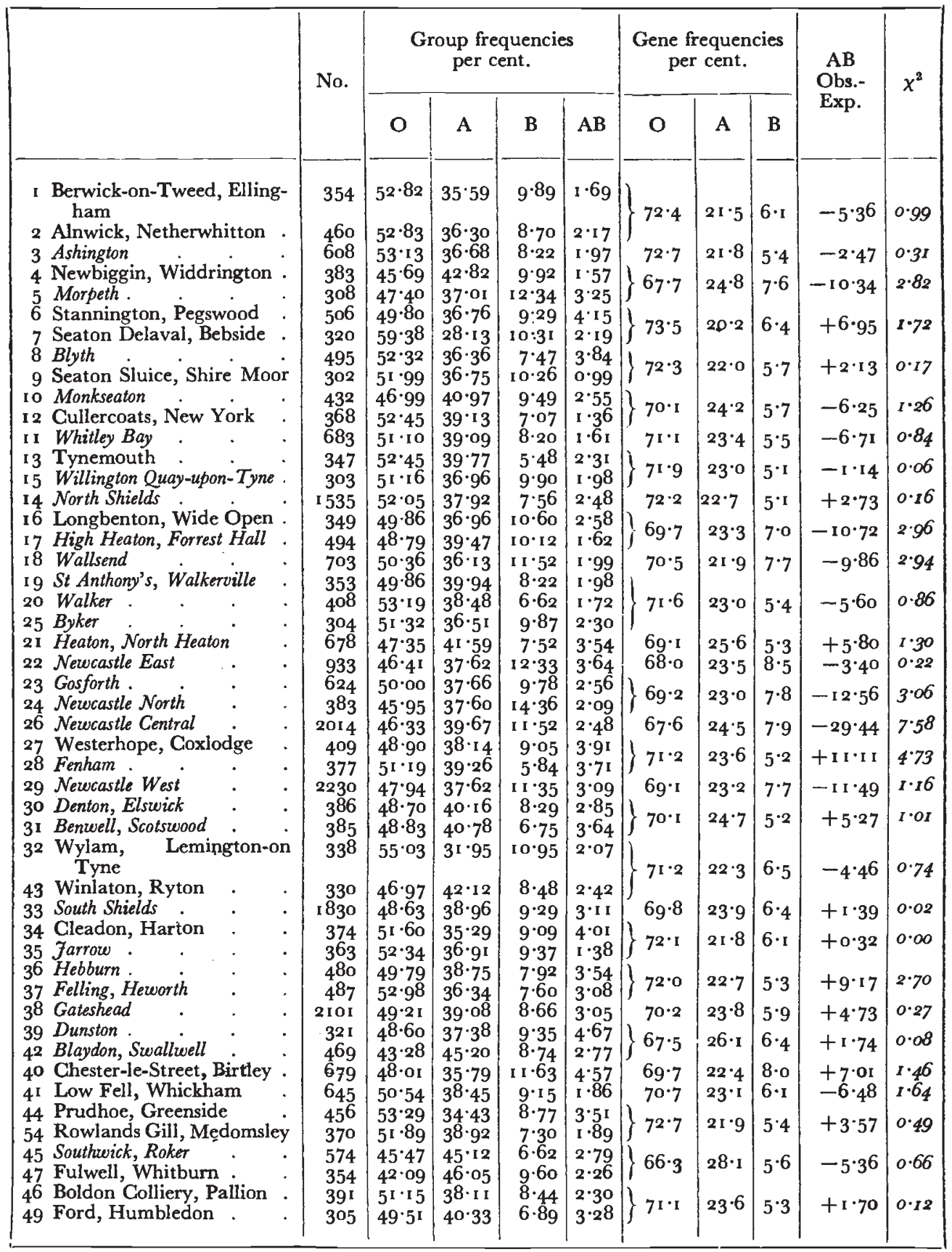


TABLE 2 (continued)

\begin{tabular}{|c|c|c|c|c|c|c|c|c|c|c|}
\hline & \multirow{2}{*}{ No. } & \multicolumn{4}{|c|}{$\begin{array}{l}\text { Group frequencies } \\
\text { per cent. }\end{array}$} & \multicolumn{3}{|c|}{$\begin{array}{l}\text { Gene frequencies } \\
\text { per cent. }\end{array}$} & \multirow{2}{*}{$\begin{array}{l}\text { AB } \\
\text { Obs.- } \\
\text { Exp. }\end{array}$} & \multirow{2}{*}{$\chi^{2}$} \\
\hline & & $\mathrm{O}$ & A & B & $\mathrm{AB}$ & $\mathrm{O}$ & A & B & & \\
\hline $4^{8}$ Sunderland & 2162 & $49 \cdot 63$ & $39 \cdot 13$ & $8 \cdot 74$ & $2 \cdot 50$ & $70 \cdot 3$ & $23 \cdot 7$ & $5 \cdot 9$ & $-7 \cdot 17$ & 0.60 \\
\hline $\begin{array}{l}\text { 5o Silksworth, Grindon } \\
5 \text { I Seaham, Ryhope }\end{array}$ & $\begin{array}{l}344 \\
396\end{array}$ & $\begin{array}{l}52 \cdot 03 \\
54 \cdot 29\end{array}$ & $\begin{array}{l}39 \cdot 24 \\
33 \cdot 33\end{array}$ & $\begin{aligned} 6 \cdot 98 \\
10 \cdot 10\end{aligned}$ & $\begin{array}{l}I \cdot 74 \\
2 \cdot 27\end{array}$ & $72 \cdot 8$ & $21 \cdot 5$ & $5 \cdot 7$ & $-3 \cdot 18$ & $0.4 I$ \\
\hline $5^{2}$ Hetton-le-Hole, Deneside & 412 & $48 \cdot 06$ & $41 \cdot 75$ & 7.04 & $3 \cdot 16$ & $70 \cdot 5$ & & & & \\
\hline 53 Stanley, Pelton & 368 & $5^{1} \cdot 3^{6}$ & $3^{8 \cdot 86}$ & $7 \cdot 6 i$ & $2 \cdot 17$ & 70.5 & $24 \cdot 5$ & 5.0 & $+\mathbf{1} \cdot 9^{1}$ & 0.14 \\
\hline & $4^{13}$ & $48 \cdot 43$ & $39 \cdot 23$ & $9 \cdot 20$ & $\begin{array}{l}3 \cdot 15 \\
2 \cdot 22\end{array}$ & $7 I \cdot 3$ & $22 \cdot 9$ & $5 \cdot 8$ & +0.57 & $0.0 r$ \\
\hline 56 Consett , Houghton-le- & $\begin{array}{l}314 \\
368\end{array}$ & $\begin{array}{l}53 \cdot 82 \\
46 \cdot 47\end{array}$ & $\begin{array}{l}35 \cdot 99 \\
40 \cdot 22\end{array}$ & $\begin{array}{r}7 \cdot 96 \\
10 \cdot 33\end{array}$ & $\begin{array}{l}2 \cdot 23 \\
2 \cdot 99\end{array}$ & 7.2 & & & & \\
\hline $\begin{array}{l}\text { Spring } \\
\text { 6o Crook, Spennymoor }\end{array}$ & 305 & 50.49 & & D. & $2 \cdot 30$ & $69 \cdot 4$ & $24 \cdot 5$ & $6 \cdot I$ & $-2 \cdot 28$ & $0 \cdot 18$ \\
\hline $\begin{array}{l}\text { 6o Crook, Spennymoor } \\
58 \text { Sedgefield, Thornley }\end{array}$ & $\begin{array}{l}305 \\
373\end{array}$ & $\begin{array}{l}50 \cdot 49 \\
47 \cdot 72\end{array}$ & $\begin{array}{l}40 \cdot 00 \\
38 \cdot 07\end{array}$ & $\begin{array}{l}7.21 \\
9 \cdot 65\end{array}$ & $4 \cdot 56$ & $60 \cdot 8$ & & $6 \cdot 7$ & $+7 \cdot 80$ & \\
\hline 59 West Hartlepool & $35^{8}$ & 48.88 & 37.99 & $9 \cdot 7^{8}$ & $3 \cdot 35$ & 69.8 & 23.5 & 0.7 & $+7 \cdot 83$ & $r \cdot 9^{2}$ \\
\hline $\begin{array}{l}6 \text { Bishop Auckland, Shildon } \\
62 \text { Willington, Barnard Castle }\end{array}$ & $\begin{array}{l}325 \\
305\end{array}$ & $\begin{array}{l}45 \cdot 85 \\
5^{1} \cdot 15\end{array}$ & $\left|\begin{array}{l}44 \cdot 00 \\
40 \cdot 00\end{array}\right|$ & $\begin{array}{l}8 \cdot 31 \\
6 \cdot 89\end{array}$ & $\begin{array}{l}I \cdot 85 \\
\text { I.97 }\end{array}$ & $69 \cdot 3$ & 25.4 & $5 \cdot 3$ & $-4 \cdot 9^{8}$ & r.03 \\
\hline 63 Kirkby Stephen, Appleby & 549 & $46 \cdot 45$ & $41 \cdot 89$ & $8 \cdot 74$ & $2 \cdot 9 \mathrm{I}$ & $68 \cdot 6$ & & $6 \cdot I$ & +3.09 & 0.25 \\
\hline 87 Penrith. & 330 & $47 \cdot 58$ & $39 \cdot 70$ & $8 \cdot 4^{8}$ & $4 \cdot 24$ & & 254 & 0.1 & $+3 \cdot 09$ & 0.25 \\
\hline $\begin{array}{l}64 \text { Darlington } \\
65 \text { Richmond, Stillington }\end{array}$ & $\begin{array}{r}2336 \\
555\end{array}$ & $\begin{array}{l}48 \cdot 4^{2} \\
49 \cdot 37\end{array}$ & $\begin{array}{l}39^{\circ} \cdot 4 \\
38 \cdot 74\end{array}$ & $\begin{array}{l}9.55 \\
9 \cdot 01\end{array}$ & $\begin{array}{l}3.00 \\
2.88\end{array}$ & $69 \cdot 7$ & $23 \cdot 9$ & $6 \cdot 5$ & $-3 \cdot 34$ & 0.09 \\
\hline 66 Saltburn, Nunthorpe & 349 & 44.70 & $42 \cdot 9^{8}$ & 10.03 & $2 \cdot 29$ & & & & & \\
\hline 67 Redcar, Dormanstown & $3^{87}$ & $50 \cdot 39$ & $3^{8} \cdot 24$ & $7 \cdot 75$ & 3.62 & $69 \cdot 0$ & $24 \cdot 8$ & $6 \cdot 1$ & -0.40 & 0.00 \\
\hline 68 Grangetown, Stainton & 503 & $47 \cdot 32$ & $\begin{array}{l}41 \cdot 15 \\
30 \cdot 64\end{array}$ & $\begin{array}{r}8.55 \\
12.26\end{array}$ & $\begin{array}{l}2 \cdot 9^{8} \\
2 \cdot 18\end{array}$ & $68 \cdot 1$ & $25 \cdot 0$ & $6 \cdot 9$ & $-5 \cdot 89$ & 0.90 \\
\hline $\begin{array}{l}69 \text { South Bank } \\
\text { 70 North Ormesby }\end{array}$ & $\begin{array}{l}275^{*} \\
614\end{array}$ & $\begin{array}{l}45 \cdot 82 \\
47 \cdot 88\end{array}$ & $\begin{array}{l}39 \cdot 64 \\
40 \cdot 55\end{array}$ & $\begin{array}{r}12.36 \\
8.96\end{array}$ & $\begin{array}{l}2 \cdot 18 \\
2 \cdot 61\end{array}$ & $69^{\circ} 0$ & $24 \cdot 8$ & $6 \cdot 2$ & $-2 \cdot 90$ & $0 \cdot 3 I$ \\
\hline $7 \mathrm{I}$ Middlesborough & 2399 & $46 \cdot 9^{8}$ & $4^{2} \cdot 3 \mathrm{I}$ & $7 \cdot 8_{4}$ & $2 \cdot 88$ & $68 \cdot 5$ & $25 \cdot 8$ & 5.7 & $+0 \cdot 00$ & 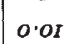 \\
\hline 72 Linthorpe & 362 & $46 \cdot 69$ & $40 \cdot 06$ & 9.94 & $\begin{array}{l}3.31 \\
2.79\end{array}$ & & & & & \\
\hline $\begin{array}{l}73 \text { Billingham } \\
74 \text { Norton }\end{array}$ & $\begin{array}{l}349 \\
466\end{array}$ & $\begin{array}{l}49^{\prime} \cdot 28 \\
44 \cdot 4^{2}\end{array}$ & $\begin{array}{l}39 \cdot 26 \\
4^{2} \cdot 06\end{array}$ & $\begin{array}{l}7.74 \\
9.44\end{array}$ & $\begin{array}{l}3 \cdot 72 \\
4 \cdot 08\end{array}$ & $68 \cdot 5$ & $25 \cdot 4$ & $6 \cdot I$ & $+6 \cdot 8 \mathrm{I}$ & $r \cdot 29$ \\
\hline 75 Thornaby, Hartburn & 682 & $48 \cdot 97$ & $37 \cdot 10$ & $10 \cdot 26$ & $3 \cdot 67$ & $70 \cdot 2$ & $22 \cdot 9$ & $7 \cdot 0$ & $+3 \cdot 28$ & 0.36 \\
\hline 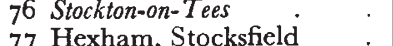 & $\begin{array}{r}1005 \\
336\end{array}$ & $47 \cdot 56$ & $42 \cdot 09$ & $\begin{array}{r}8.06 \\
8 \cdot 12\end{array}$ & $\begin{array}{l}2 \cdot 29 \\
2 \cdot 68\end{array}$ & & $25 \cdot 6$ & $5 \cdot 6$ & $-6 \cdot 03$ & \\
\hline $\begin{array}{l}77 \text { Hexham, Stocksteld } \\
78 \text { Haydon Bridge, Bellingham }\end{array}$ & $\begin{array}{l}336 \\
306\end{array}$ & $\begin{array}{l}5^{1} \cdot 49 \\
5^{2} \cdot 94\end{array}$ & $\begin{array}{l}35 \cdot 7 \mathrm{I} \\
37 \cdot 9 \mathrm{I}\end{array}$ & $\begin{array}{r}10 \cdot 12 \\
6.21\end{array}$ & $\begin{array}{l}2 \cdot 68 \\
2 \cdot 94\end{array}$ & $72 \cdot 4$ & $22 \cdot I$ & 5.5 & $+2 \cdot 40$ & 0.27 \\
\hline 79 Longtown, Brampton & $\begin{array}{l}302 \\
333\end{array}$ & $\begin{array}{l}54 \cdot 30 \\
51 \cdot 35\end{array}$ & $\left|\begin{array}{l}31 \cdot 13 \\
34 \cdot 83\end{array}\right|$ & & $\begin{array}{l}3.97 \\
3.00\end{array}$ & $7^{2} \cdot 9$ & $20 \cdot I$ & $7 \cdot 1$ & $+4 \cdot 13$ & $0 \cdot 7 r$ \\
\hline $\begin{array}{l}\text { 80 Harraby, Scotby } \\
\text { 81 Stanwix. }\end{array}$ & $\begin{array}{l}333 \\
353\end{array}$ & $\begin{array}{l}5 \mathrm{I} \cdot 35 \\
5^{8} \cdot 07\end{array}$ & $\begin{array}{l}34 \cdot 83 \\
30 \cdot 03\end{array} \mid$ & $\begin{array}{r}10 \cdot 81 \\
9.92\end{array}$ & $\begin{array}{l}3.08 \\
1 \cdot 98\end{array}$ & & & & -0.80 & \\
\hline 82 Carlisle & 3260 & $52 \cdot 39$ & 35.67 & $9 \cdot 5^{1}$ & $2 \cdot 42$ & $72 \cdot 7$ & $2 \mathrm{I} \cdot \mathrm{I}$ & $0 \cdot 3$ & $-9 \cdot 80$ & 0.74 \\
\hline 83 Silloth, Workington & 601 & $51 \cdot 75$ & $38 \cdot 27$ & $7 \cdot 32$ & $2 \cdot 66$ & & & & & $r \cdot m$ \\
\hline 84 Maryport & 349 & $\begin{array}{l}53.58 \\
55.82\end{array}$ & $36 \cdot 68$ & $7 \cdot 45$ & $\begin{array}{l}2 \cdot 29 \\
2 \cdot 06\end{array}$ & $72 \cdot 7$ & $22 \cdot 5$ & $4 \cdot 9$ & $+6 \cdot 26$ & $1 \cdot \infty$ \\
\hline $\begin{array}{l}85 \text { Whitehaven, Cleator Moor } \\
86 \text { Keswick, Ambleside }\end{array}$ & $\begin{array}{l}371 \\
386\end{array}$ & $\begin{array}{l}52 \cdot 83 \\
47 \cdot 67\end{array}$ & $\begin{array}{l}37 \cdot 20 \\
40 \cdot 93\end{array}$ & $\begin{array}{l}7.01 \\
9.07\end{array}$ & $\begin{array}{l}2 \cdot 90 \\
2 \cdot 33\end{array}$ & 68.6 & $\cdots$ & $6 \cdot 0$ & & 0.00 \\
\hline 88 Windermere, Coniston & 307 & $47 \cdot 23$ & $3^{8 \cdot 76}$ & II $\cdot 07$ & $2 \cdot 93$ & 000 & 245 & 109 & $-54 /$ & go \\
\hline 89 Kendal Kirkby & 395 & $\begin{array}{l}50 \cdot 89 \\
40 \cdot 60\end{array}$ & $\left|\begin{array}{|c|}37 \cdot 22 \\
30.72\end{array}\right|$ & \begin{tabular}{|ll}
10.13 \\
7.72
\end{tabular} & $\begin{array}{l}1 \cdot 77 \\
2 \cdot 03\end{array}$ & $70 \cdot 7$ & $23 \cdot 2$ & 6.I & -3.74 & $0.46^{\circ}$ \\
\hline 90 Kirkby Lonsdale, Arneside & 375 & $49 \cdot 60$ & $39 \cdot 73$ & $7 \cdot 73$ & & & & & & \\
\hline Total $54,579 \quad \mathrm{O}, 49.484$ & $A, 38 \cdot 6$ & 7. $\mathrm{P}$ & . & & & $70 \cdot 3$ & 23.5 & $6 \cdot 2$ & $-87 \cdot 13$ & $3 \cdot 4 r$ \\
\hline
\end{tabular}

Notes.-1. Numbers in groups can be reconstructed from totals and percentages.

2. Names in italics denote areas composed of single towns, parts of towns, or closely adjacent urban localities.

3. When possible double names indicate extent of area.

* A mistake was made in keeping South Bank separate at the 300 donor stage. Rearrangement of the areas would have been troublesome and was not attempted. 


\section{GEOGRAPHICAL VARIATIONS}

(i) Frequencies of genes $O$ and $A$

The maps show the frequencies of the three genes, giving each of the $5^{2}$ areas separately. It will be realised that the approach to this pilot investigation has been empirical. The main purpose of the survey was to test the nature and reliability of the recorded data and to see what relatively fine fluctuations may exist that the records of the National Blood Transfusion Service can be expected to elucidate and which it might be profitable to study in other areas in the future. Moreover, such analysis as has been carried out so far on this material using the family names gives the hope that further useful information will be forthcoming. This will be dealt with in another paper. For the moment, it seems best to look at the figures as they stand, simply in terms of the $5^{2}$ areas, without attempting to make alternative additions, and see what deductions can be drawn. More detailed analysis in the light of the history and geography of the area can follow later.

Inspection of the $\mathrm{O}$ and $\mathrm{A}$ maps strongly suggests that much the most important feature in the variability of the frequencies of these genes is the south-north gradient in $\mathrm{A}$ and $\mathrm{O}$ frequencies. $\mathrm{A}$ number of experiments were tried and it soon became clear that it is possible to draw a single line from east to west, dividing the whole region into two in such a way that the two areas are homogeneous within themselves and all the significant heterogeneity lies between them, as shown in table 3 .

TABLE 3

Analysis of the heterogeneity of the 52 areas in respect of the variability of $O$ and $A$. Division of region into two, as indicated on $O$ map

\begin{tabular}{|c|c|c|c|c|}
\hline & & No. of donors & No. of areas & $\mathrm{O} /(\mathrm{O}+\mathrm{A})$ per cent. \\
\hline Northern & . & 19,460 & 20 & $41 \cdot 43$ \\
\hline Southern & . & 35,119 & $3^{2}$ & $45 \cdot 19$ \\
\hline Total & . & 54,579 & $5^{2}$ & $\ldots$ \\
\hline
\end{tabular}

\begin{tabular}{|c|c|c|c|c|}
\hline Variation & & D. of F. & $\chi^{2}$ & $\mathbf{P}$ \\
\hline $\begin{array}{l}\text { Within northern areas } \\
\text { Within southern areas } \\
\text { Between the two areas }\end{array}$ & : & $\begin{array}{r}19 \\
31 \\
1\end{array}$ & $\begin{array}{l}16 \cdot 19 \\
38 \cdot 43 \\
63 \cdot 44\end{array}$ & $\begin{array}{c}0.64 \\
0.17 \\
<0.0001\end{array}$ \\
\hline Between all areas & . & 51 & $118 \cdot 06$ & $<0.0001$ \\
\hline
\end{tabular}


The line is shown on the $\mathrm{O}$ map, though in drawing it regard was also paid to the A percentages, and indeed principally to the A : O ratio. Starting in the west it is perfectly clear where the line must be drawn right up to the densely populated Newcastle area which is shown on an enlarged scale. Western Cumberland with its industrial areas lies to the north of the line. Is this due to relatively recent industrial immigration from Scotland and Ireland, or, as seems more probable, is it an indication of much older Celtic affinities? Carlisle lies definitely to the north ; Penrith equally definitely to the south; Hexham lies north. The line turns northwards as it approaches Newcastle, but leaves Consett to the north. It then passes through the middle of the area of dense population. Newcastle itself represents an upward bulge, but the region of higher $\mathrm{O}$ and lower A comes in close on the western side of the City. Even more remarkably, the coastal area north of the River Tyne, including Whitley Bay, North Shields and Tynemouth, shows high O, as do Jarrow and Hebburn, south of the river, together with Wallsend and adjacent areas to the north.

To the north of Newcastle there is some irregularity. Morpeth (to which has been added Newbiggin) appears to belong to the region of lower $\mathrm{O}$; the difference from the areas surrounding it being highly significant ( $\chi^{2}$, with Yates's correction, is 7.54$)$. This district was one of the earliest to be dealt with, and the arrangement of the areas finally proved to be about the least satisfactory of any in the survey. It may be that Morpeth represents serologically a northward continuation of Newcastle, though it is difficult to think of any reason why this should be so. In fact, had the areas in the rather sparsely populated districts between them been differently demarcated and differently added, Morpeth might indeed have appeared as continuous with Newcastle. On the other hand one cannot help viewing the Morpeth figures with some suspicion and it may be that a fresh count on larger numbers would not confirm the frequencies now given. It is hoped to make such a count and the results will be reported in the next paper. For the time being, however, the town has been classified provisionally with the southern area of higher A.

South of the line, the area based on Ryhope and Seaham Harbour is high in $\mathrm{O}$, showing 73 per cent.; but tested against the areas which surround it, the difference is not significant $\left(\chi^{2}=3 \cdot 04\right)$. Consequently it does not seem necessary to show an island of high $\mathrm{O}$ here.

Naturally, it is possible to vary the exact position of the line somewhat without making either the northern or the southern area significantly heterogeneous. This hardly applies, however, outside the densely populated area and even here there is considerably less freedom of choice than might appear. In any event, however, it is drawn, the line must pass right through the densely populated area. 


\section{GENE O}

FREQUENCY - PER CENT
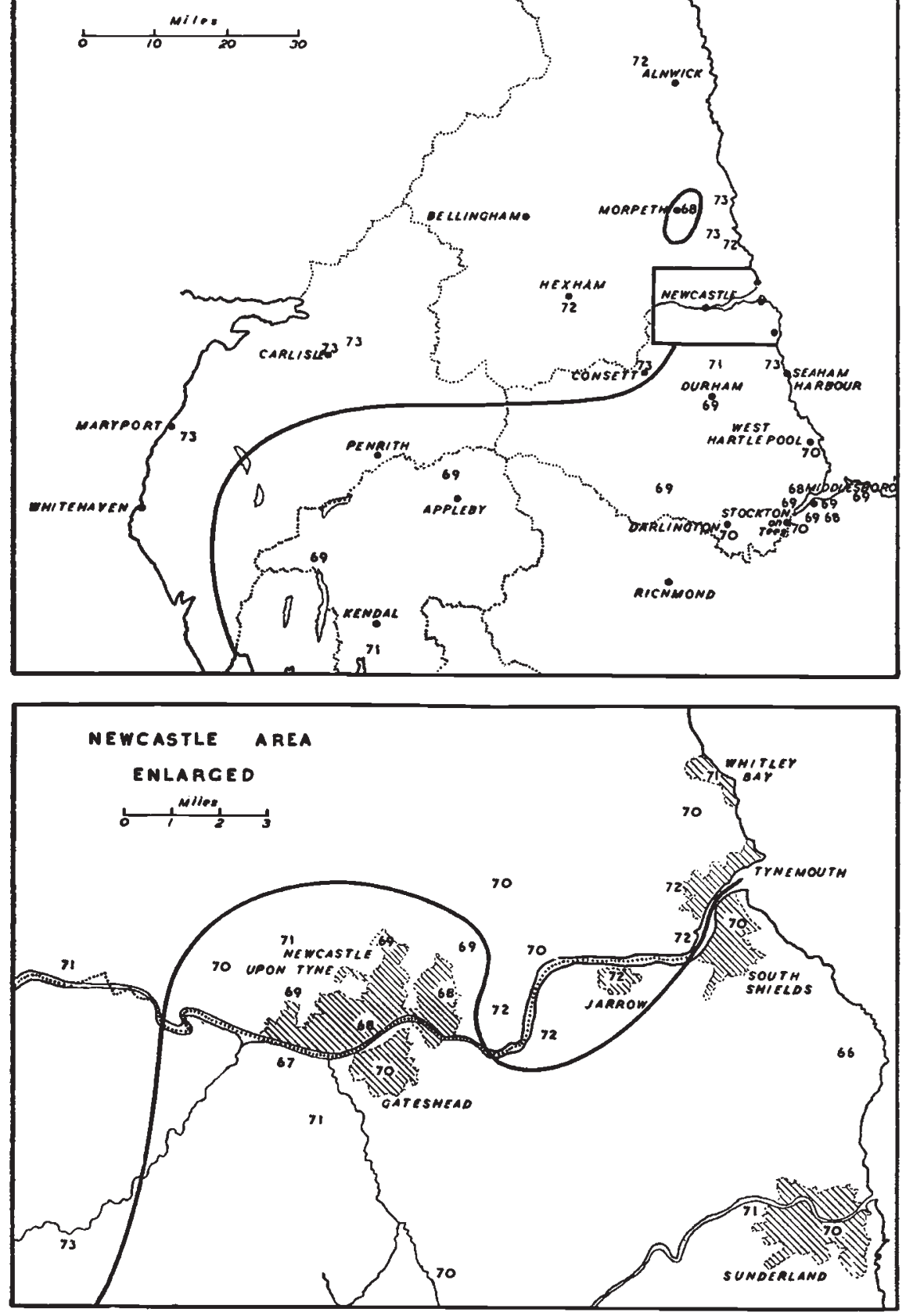

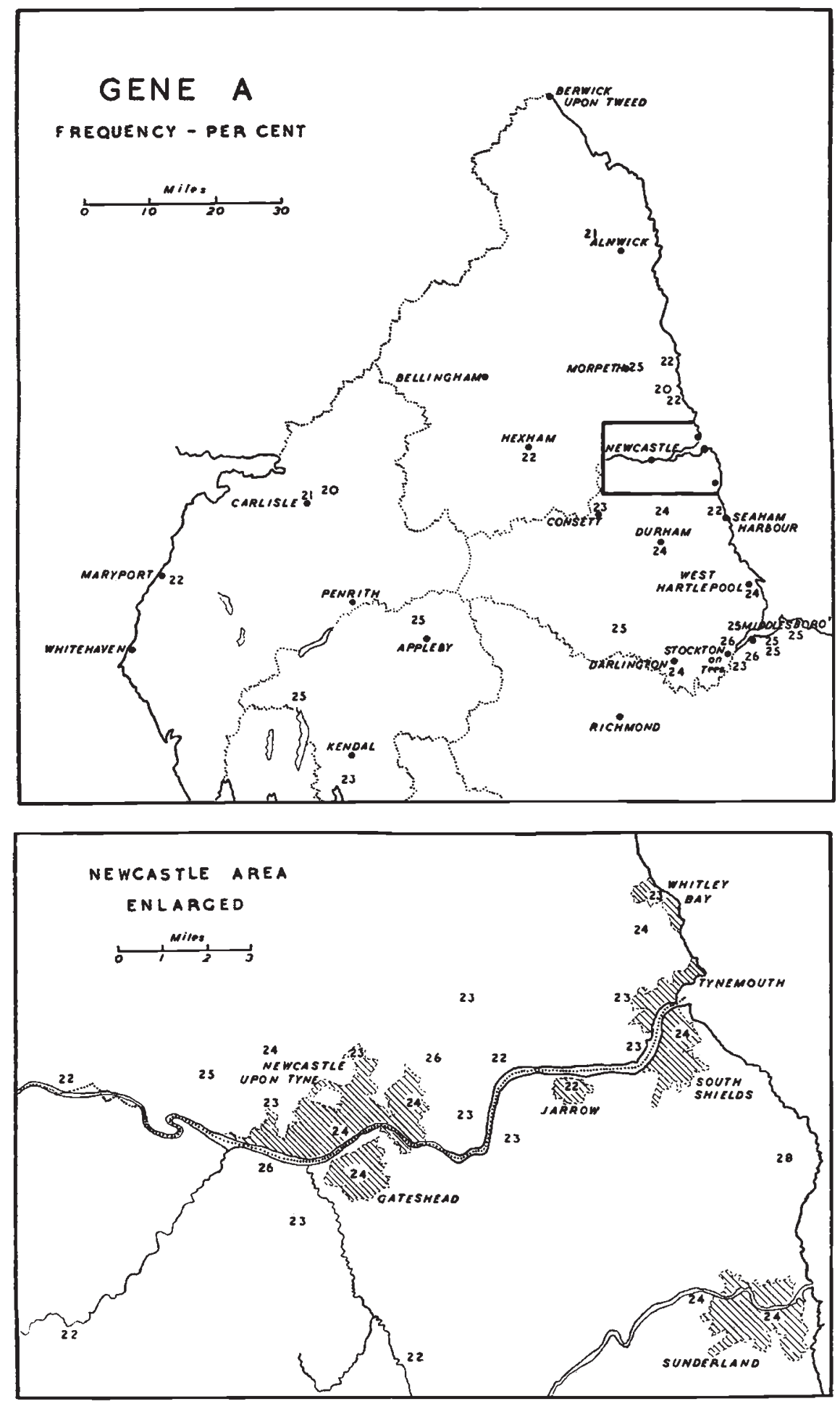
The strong evidence that in this region of England the northward rise in the frequency of gene $\mathrm{O}$ and the largely reciprocal fall in gene $\mathrm{A}$ is not a matter of gradual change, but is instead a step taking place at a remarkably definite line, prompts the suggestion that this may be generally true of the south-north gradient of England and Scotland taken as a whole; namely, that the two countries can be divided into four (or perhaps five) areas within each of which there is relatively little variation in $\mathrm{O}$ and $\mathrm{A}$, but that where they adjoin there is a marked change which occurs over a very short distance. It is interesting, therefore, to examine Fisher's figures for Yorkshire in some detail ; these are given in a communication which reported a sex difference (Fisher and Roberts, 1943). Only the figures for groups $\mathrm{O}$ and $\mathrm{A}$ have been published as it was thought that there might be inaccuracies which would make it unsafe to use the figures for the other groups. Hence it is necessary to work in terms of the ratio $\mathrm{A} /(\mathrm{O}+\mathrm{A})$. (I was tempted to replace the $\mathrm{O}$ and $\mathrm{A}$ maps by a single map showing this useful ratio, but did not do so because gene frequency maps are now so universal.) Fisher's figures, with some calculations, are reproduced in table 4 .

The area taken as a whole is highly heterogeneous, $\chi^{2}$ for Io degrees of freedom being 82.97 . It is clear, however, that the great bulk of the variability is due to a difference between the southern part of the county and the remainder. Sheffield, Halifax, Huddersfield and Wakefield taken together give a $\chi^{2}$ of 10.30 for 3 degrees of freedom. This is significant, but not highly so. The heterogeneity is due to the relatively low figure for Huddersfield, which must be included in the southern area because it lies to the south of Halifax. The whole of the rest of the area when these four centres are omitted is homogeneous, $\chi^{2}$ being only I0.94 for 6 degrees of freedom. The large residual area, West Riding, less Skipton and Settle, ought perhaps to be omitted, as it may contain areas in the south of the county. Its omission, however, makes no appreciable difference. The $\mathrm{A} /(\mathrm{O}+\mathrm{A})$ figure for the southern area is $48 \cdot 0$ and for the northern $45^{\circ} 8$.

The line of division is remarkably clear although the centres are so large. It follows the River Humber and then the River Aire,* except that Leeds, which is situated on the Aire, and Bradford, slightly to the south of it, must be allotted to the northern part of the county. This is a line of outstanding importance in the history of England. Belloc (1912) points out that east of the Pennines the Aire was the natural barrier between north and south, the distance from the mountains to the marshes lining the estuary of the Humber being no more than twenty miles. The crossing was dominated by Pontefract.

\footnotetext{
* I have the impression that a number of years ago I read or heard it stated that the change from south to north in OA blood-group frequencies took place about the line of the River Wharfe (somewhat to the north of the Aire) ; but I have been unable to verify this or trace a reference.
} 
On the other side of the Pennines there was a corresponding barrier formed by a natural belt of marshes along the valley of the Mersey, with a narrow gap at Stockport, dominated by Manchester. Whoever held Pontefract and Manchester held the gateways to the north, or south. It is not possible, however, to link up the line of the present survey with anything so definite, except that the River Tyne was also an important barrier.

TABLE 4

Fisher's data for groups $O$ and $A$ in Yorkshire, with an attempt at division into northern and southern portions

\begin{tabular}{|c|c|c|c|c|c|}
\hline & & & $\mathrm{O}$ & A & $\begin{array}{c}\mathrm{A} /(\mathrm{O}+\mathrm{A}) \\
\text { per cent. }\end{array}$ \\
\hline \multicolumn{6}{|l|}{ Northern } \\
\hline Leeds & . & . & I I 359 & 9,805 & $46 \cdot 33$ \\
\hline Bradford & . & . & II, 383 & $9,76 \mathrm{I}$ & $46 \cdot I 6$ \\
\hline Hull . & . & . & 6,867 & 5,783 & $45 \cdot 72$ \\
\hline E. Riding . & . & . & $\mathrm{I}, 929$ & 1,630 & $45 \cdot 80$ \\
\hline Vale of York & & & 4,253 & 3,726 & $46 \cdot 70$ \\
\hline W. Riding (les & Skipton and & Settle) & 23,406 & I 9,488 & $45 \cdot 43$ \\
\hline Skipton and $\mathrm{Se}$ & ttle & . $\quad$. & 2,108 & $\mathrm{I}, 69 \mathrm{I}$ & $44^{\circ} 5^{I}$ \\
\hline Total & . & . & 61,305 & $5 \mathrm{I}, 884$ & $45^{\cdot 84}$ \\
\hline \multicolumn{6}{|l|}{ Southern } \\
\hline Sheffield & . & . & I 4,930 & $14,03 \mathrm{I}$ & $48 \cdot 45$ \\
\hline Wakefield & . & . & 3,123 & $2,79 \mathrm{I}$ & $47 \cdot 19$ \\
\hline Huddersfield & . & . & 3,245 & 2,806 & $46 \cdot 37$ \\
\hline Halifax & - & . & $3,5^{20}$ & 3,260 & $48 \cdot 08$ \\
\hline Total & . & . & 24,818 & 22,888 & $47 \cdot 98$ \\
\hline
\end{tabular}

\begin{tabular}{|c|c|c|c|}
\hline Variation & D. of $F$. & $\chi^{2}$ & $\mathbf{P}$ \\
\hline $\begin{array}{l}\text { Within northern areas } \\
\text { Within southern areas } \\
\text { Between northern and southern areas }\end{array}$ & $\begin{array}{l}6 \\
3 \\
1\end{array}$ & $\begin{array}{l}10 \cdot 94 \\
10 \cdot 30 \\
61 \cdot 73\end{array}$ & $\begin{array}{c}0.090 \\
0.016 \\
<0.0001\end{array}$ \\
\hline Within whole area & Io & $82 \cdot 97$ & $<0.000 \mathrm{I}$ \\
\hline
\end{tabular}

The AO figure for the 4 centres comprising southern Yorkshire is $48 \cdot 0$; this includes the large Sheffield area with a ratio of 48.4 . These figures are very little lower than those for southern England. Fisher and Taylor's (1940) figure for south-eastern England is 48.8 ; Dobson and Ikin's (1946) for Cambridge is 48.7 . Mine (Roberts, I 948 ) for the southwest is 49.7 ; but I suspect, for reasons given in that paper, that it is a little too high. Thus it seems clear that there is very little change in the proportion of genes $\mathrm{O}$ and $\mathrm{A}$ over an area which extends from the English Channel as far north as Sheffield, Halifax and Wakefield. Information is not yet sufficient to decide 
whether a corresponding line can be drawn west of the Pennines and where it would lie. It would be interesting should it prove to pass through the Manchester area.

Fisher's northern Yorkshire area adjoins the southern part of the region described in the present paper. The $A O$ ratio is $45 \cdot 8$, which turns out to be identical to three figures with an area comprising Darlington, Stockton-on-Tees, Middlesborough and West Hartlepool (Areas 58,59 and 64 to 76 inclusive of table 2). The rest of the area south of the line on the $\mathrm{O}$ map gives 44.9 , which is not significantly different from that for the area just defined $\left(\chi^{2}=2 \cdot 00\right)$. Thus there is practically no change in $\mathrm{O}$ and $\mathrm{A}$ over a region which includes Leeds, Bradford and Hull and extends as far north as (most of) Newcastle.

Such figures as are available suggest that the AO ratio for most of Scotland is not very different from that found in the northern area of the present paper. Fisher and Taylor's (1940) data give 39.7. In the Highlands there is a further fall with certain areas showing very low values.

Mourant and Watkin (1952) in their maps of Western Europe show isogene lines at intervals of 5 per cent. The scale is, of course, small and it was intended to display broad trends only, but on the results of the present inquiry it would seem that the $\mathrm{O}$ isogene of 70 is drawn too far to the south. Incidentally, if the arguments of this section are accepted, it becomes difficult to draw isogene maps at all for Britain. It will be necessary rather to separate large areas and allot a figure to each instead of to the lines of division between them.

One last question remains : is there any evidence of local variability underlying the apparent homogeneity of the two areas into which the region is divided? Apparently there is not; $\mathrm{O}$ and $A$ are quite unlike $B$ in this respect, as is shown in the following section. One of the 52 areas does, however, stand out ( $45+47$ of table 2); this is situated on the northern outskirts of Sunderland and includes Fulwell, Roker, Monswearmouth and Southwick, together with an area round Whitburn to the north. The frequency of $O$ is 66 and of A 28 (the figures have been placed a little too far north on the map). Actually there were 4 ro O's and 422 A's, giving $A /(O+A)=$ $50 \cdot 7$, a ratio which differs with high significance from that of the surrounding areas taken i ugether $\left(\chi^{2}=13 \cdot 68\right)$. Fortunately the Sunderland area can be examined further, because Miss P. McCracken, the organising secretary in that area, has made an alternative division in the light of local knowledge. Her areas were coded and punched on the cards. The analysis will be made later and reported in another paper, dealing principally with family names, in which paper a more detailed examination of the whole region will be undertaken. With this one exception, the figures of the $\mathrm{O}$ and $\mathrm{A}$ maps do not suggest non-significant local variations which might be established with larger numbers. This is very different from the B map. Apparently, 
therefore, in this region genes $\mathrm{O}$ and $\mathrm{A}$ do not display much local variability that cannot be accounted for by the transition from one area to another as part of the general south-north gradient of Britain.

\section{(ii) Frequency of gene $B$}

It has been usual to think of gene $B$ as showing little variation in frequency throughout Britain. The figure of 6 per cent. very fairly represents England, or any reasonably large part of it. There is a slight but real rise to 7 in Scotland, Ireland and North Wales. Apart from this there is little or nothing in the way of a gradient. Recently, Watkin (Mourant and Watkin, I952) has demonstrated some remarkable fluctuations of B in Wales, with very high frequencies in three areas described by Fleure as showing evidence of palæolithic survival. Moreover, in other areas in Wales and the Welsh Border there seems to be appreciable variability.

In the present study the 52 , ic ic areas are highly heterogeneous, the $\mathrm{B}$ gene frequencies ranging irom 4.9 to 8.5 per cent. It seems impossible, however, to discern any general gradient comparable to that shown by $\mathrm{O}$ and $\mathrm{A}$. It is a question, rather, of apparently capricious local variations from place to place. It is not difficult, however, to single out the relatively few areas which are responsible for most of the heterogeneity. An analysis is shown in table 5 .

TABLE 5

\section{Analysis of the 52 areas in respect of the variability}

of the frequency of $B$

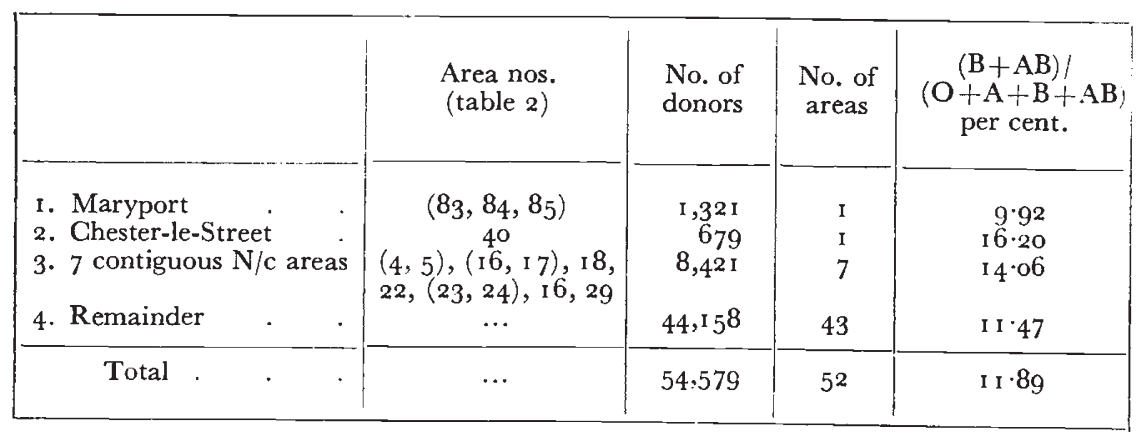

\begin{tabular}{|c|c|c|c|c|c|}
\hline Variation & & & D. of F. & $\chi^{2}$ & $P$ \\
\hline $\begin{array}{l}\text { 1. Maryport } \\
\text { 2. Chester-le-Street } \\
\text { 3. } 7 \text { contiguous } \mathrm{N} / \mathrm{c} \text { areas } \\
\text { 4. Remainder } \\
\text { Between the } 4 \text { groups }\end{array}$ & . & . & $\begin{array}{r}\cdots \\
\cdots \\
6 \\
42 \\
3\end{array}$ & $\begin{array}{l}\cdots \\
\ldots \\
5 \cdot 67 \\
44 \cdot 19 \\
61 \cdot 83\end{array}$ & $\begin{array}{c}\ldots \\
\ldots .46 \\
0.39 \\
<0.000 \text { I }\end{array}$ \\
\hline Between all areas & . & . & $5^{\mathrm{I}}$ & $I I I \cdot 69$ & $<0.000 \mathrm{I}$ \\
\hline
\end{tabular}

Note. - The figure 8.5 on the $\mathrm{B}$ map is that for Newcastle East. This is a residual area and so is continuous with the area shown as 7.7 . 


\section{GENE B}

FREQUENCY-PEA CENT
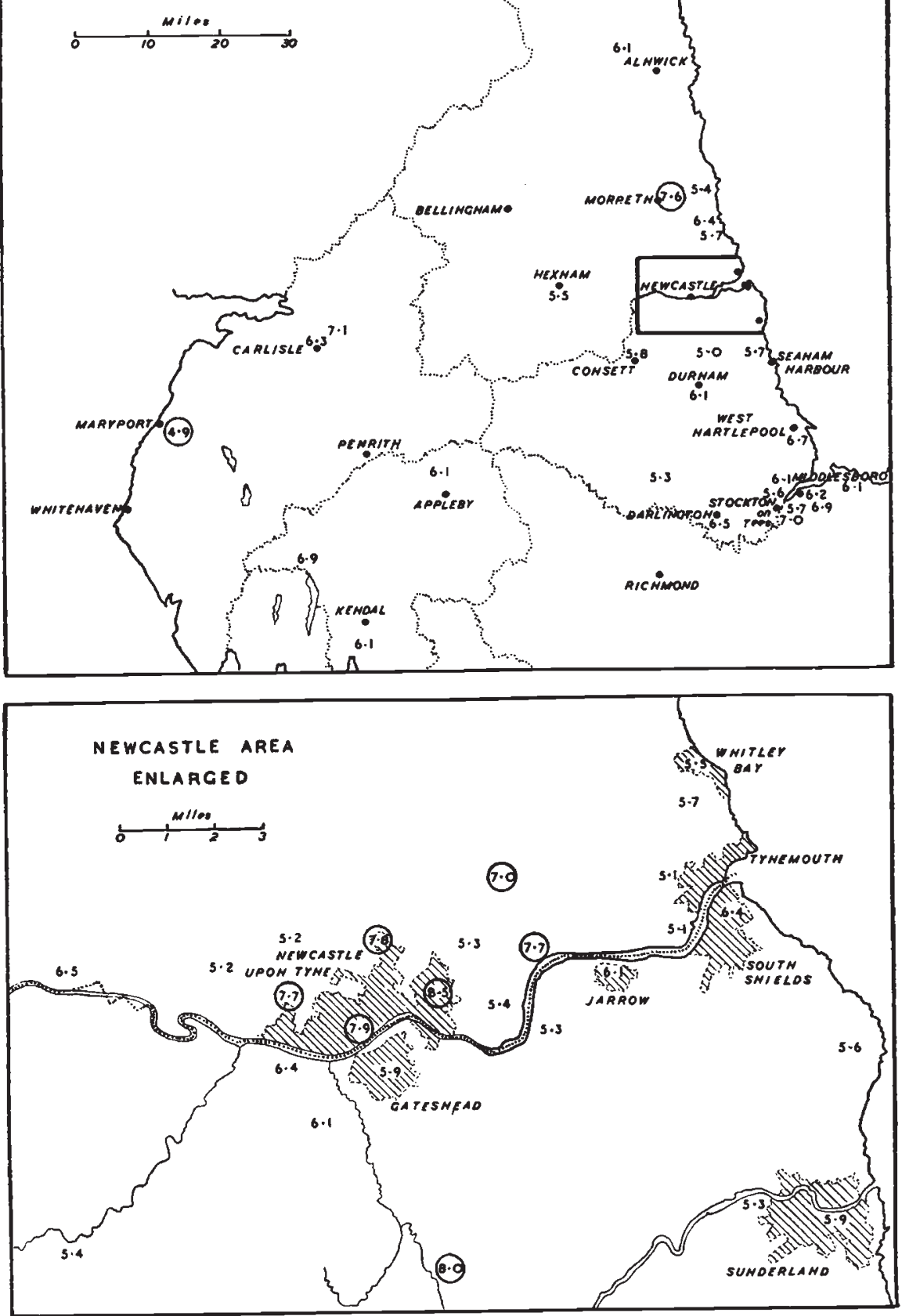
One area which stands out is the Cumberland coast, with the lowest B frequency of any area. These $132 \mathrm{I}$ donors are made up by the addition of three areas at the 300 donor stage, as is shown in table 2, and it may be noted that the frequencies are closely similar in all three. If $(\mathrm{B}+\mathrm{AB}) /(\mathrm{O}+\mathrm{A}+\mathrm{B}+\mathrm{AB})$ for this area is compared with that for all the other donors west of the Pennines, the difference is significant $\left(\chi^{2}=5^{\circ} \circ 9\right)$.

Centred on Newcastle is a group of six areas of very high B, as specified in table 5. To these must be added Morpeth, which, as was shown in the preceding section, may be provisionally considered as contiguous with Newcastle. The seven areas, though they are contiguous, do not combine into any kind of rounded whole which might be taken to represent the city, still less the greater Newcastle area. For example, the ratio for Gateshead, just across the river, differs significantly from that for the four divisions of Newcastle $\left(\chi^{2}=9 \cdot 64\right)$. Similarly, the Denton area, embedded in Newcastle West, is significantly lower in B. As between themselves the seven areas of high $\mathrm{B}$ are homogeneous.

Chester-le-Street with Birtley shows the very high frequency of $8 \cdot 0$ per cent. Though quite near Newcastle, it is not contiguous with the seven areas just described, being separated from them by Gateshead and adjoining areas. Comparing the Chester-le-Street area with the areas surrounding it taken together, the difference is highly significant $\left(\chi^{2}=15.83\right)$. It is thus a circumscribed island of very high $\mathrm{B}$.

Having deducted the foregoing 9 areas, the remaining 43 are not significantly heterogeneous, as is shown in table 5 , and there is little suggestion of any other wide variations. Nevertheless, the B map does suggest that throughout the region there are other local variations, which might become significant with larger numbers. To take an example, a composite area comprising Middlesborough, Stockton-onTees, Darlington and West Hartlepool is significantly higher in B than the area adjoining it and comprising Bishop Auckland, Durham, Stanley and Seaham Harbour $\left(\chi^{2}=5 \cdot 11\right)$.

Thus it would appear, if the northern region is representative of the country as a whole, that underlying the apparent constancy of B frequency there is a complex pattern of local variation. The apparent constancy is due to the absence of general gradients, so that if areas large enough to smooth out local variations are counted, much the same figure emerges from any part of the country.

Populations may presumably grow unlike, for even in industrial areas there is some measure of effective semi-isolation. As has been well said, large cities and towns, apart perhaps from their centres, are really collections of villages. Presumably too a gene like B of relatively low frequency is more subject to chance effects producing higher or lower frequencies than are genes like $\mathrm{O}$ and $\mathrm{A}$, which are common everywhere. 
(iii) Conclusion on geographical variation, with a word on social differences and on urban and rural areas

Any study of gradients and more particularly of heterogeneity in general is related to the numbers available for study. With relatively small numbers gradients can only be worked out very broadly and even wide local fluctuations over small areas may not be discerned at all. Each addition to numbers permits analysis at a new level ; and it is always possible that at some further stage a hitherto unsuspected pattern of variability may emerge. Who can say what might be revealed should numbers become so large that very small areas can be compared and half per cent. differences can be established? Nevertheless, on the relatively large numbers of the present study fairly definite conclusions can be drawn.

Variations in the frequencies of genes $\mathrm{O}$ and $\mathrm{A}$, which are largely reciprocal, depend upon the general change which is found as one passes from south to north, or west into North Wales. The change is apparently not a gradual one, but takes place in a series of steps. In the regions where the steps take place there are big variations between places situated quite close together, though when numbers are large enough it is likely that fairly definite lines demarcating the main areas can be drawn without much difficulty. The first line of division is situated about the line of the River Aire in Yorkshire. A corresponding line may be established in Lancashire, but the counts are at present insufficient to make sure of this. The next step is that illustrated in the $\mathrm{O}$ map. The third may be found to separate the Highlands from the Lowlands in Scotland; and there are indications either of a further change within the Highlands, or perhaps of islands of extremely high $\mathrm{O}$. The variability within the regions so separated is relatively small. Apart from the general gradient just described there appears to be little local variability in the frequencies of $\mathrm{O}$ and $\mathrm{A}$. If such local variability does exist it must be confined to very small differences which could only be demonstrated by larger nums.rs than are available at present. This does not mean, however, that special areas, with a special history, may not show differences, for example Watkin's (I95I) high A in an area of Pembrokeshire and about Chester, which may reflect Viking settlement.

The frequency of the B gene shows exactly the opposite kind of variability. There is very little in the way of any general gradient, apart from a one per cent. rise in Scotland, Ireland and North Wales. On the other hand there is relatively great local fluctuation from place to place, sometimes over quite small areas. Future work will no doubt show whether these variations can be related to history and geography or whether it is more a matter of chance differences.

It would seem from the data of the present paper that there is little if any difference between urban and rural areas in the same locality. Migration must have a diluting effect and no doubt the 
variations found to-day are smaller than those that once existed; but it would seem that urbanisation is too recent a process to have established much relation to blood-group frequencies. The towndwellers of to-day are but the descendants of the countrymen of four or five generations ago. Apart from the relatively high $\mathrm{A}$ of most of Newcastle, which may represent a northward extension into a more rusal area, it is in fact remarkable how similar are the frequencies in rural and semi-rural areas to those of the towns they contain. It is hoped to give more evidence on this point in a further paper.

Nor is there any evidence that social differences are reflected by blood-group frequencies. There is some indirect information on this in the present data. Thus no two parts of a city could differ more in social conditions than do Newcastle East and Newcastle North; yet there is no sign of any corresponding difference in blood-groups. So presumably social differences also are too recent and too inconstant to have established any appreciable relation to the frequencies of the $\mathrm{ABO}$ genes. Further observations might be useful, particularly an occupational classification of donors, but one question at least which this pilot enquiry was designed to elucidate has been answered : it is well worth while pursuing the fluctuations of genes through the apparent complexities of the factories, the offices, the slag-heaps and the pitheads.

\section{SPECIAL COMPARISONS}

\section{(i) A special panel of donors at Newcastle}

Employees of the Ministry of National Insurance at Newcastleupon-Tyne formed a special panel whose record cards were kept separately. In the counts of this paper they have been allotted to the various areas according to home address. An indication was, however, punched on the cards and so it was possible to discover whether their blood-group frequencies differed from those of the areas in which they are living. It was originally thought that they might include enough donors of non-local origin to affect the frequencies, though later enquiries by Mr Holland showed that this was not so. But in any event it is worth looking at a special occupational group to see whether it differs from the rest of the population.

The result is shown in table 6 . Those whose homes are north of the line on the $\mathrm{O}$ map are closely similar in $\mathrm{O}$ and $\mathrm{A}$ to the rest of the population of that area; those whose homes lie south of the line resemble the donors of the southern part of the Region. In the same way those living within the 8 areas of high $\mathrm{B}$, as defined in table 5 , are high in $\mathrm{B}$; those living outside the 8 areas share the relatively low B of t'ie remaining homogeneous 43 areas of Table 5. Apparently, then, a special occupational grouping is not associated with any difference in frequencies as compared with other donors living in the same localities. 
TABLE 6

Comparison of a special panel, employees of the Ministry of National Insurance, with the remainder, by areas

\begin{tabular}{|c|c|c|c|c|c|c|}
\hline & \multicolumn{6}{|c|}{$\mathrm{A} /(\mathrm{O}+\mathrm{A})$} \\
\hline & \multicolumn{3}{|c|}{ Northern area (table 3 ) } & \multicolumn{3}{|c|}{ Southern area (table 3) } \\
\hline & No. $(\mathrm{O}+\mathrm{A})$ & $\mathrm{A} /(\mathrm{O}+\mathrm{A})$ & $x^{2}$ & No. $(\mathrm{O}+\mathrm{A})$ & $\mathrm{A} /(\mathrm{O}+\mathrm{A})$ & $\chi^{2}$ \\
\hline $\begin{array}{l}\text { M.N.I. } \\
\text { Remainder }\end{array}$ & $\begin{array}{r}280 \\
16,985\end{array}$ & $\begin{array}{l}4^{2 \cdot} \cdot 5^{0} \\
4^{1} \cdot 4^{1}\end{array}$ & 0.09 & $\begin{array}{r}576 \\
30,249\end{array}$ & $\begin{array}{l}46 \cdot 01 \\
45 \cdot 17\end{array}$ & $0 \cdot 13$ \\
\hline
\end{tabular}

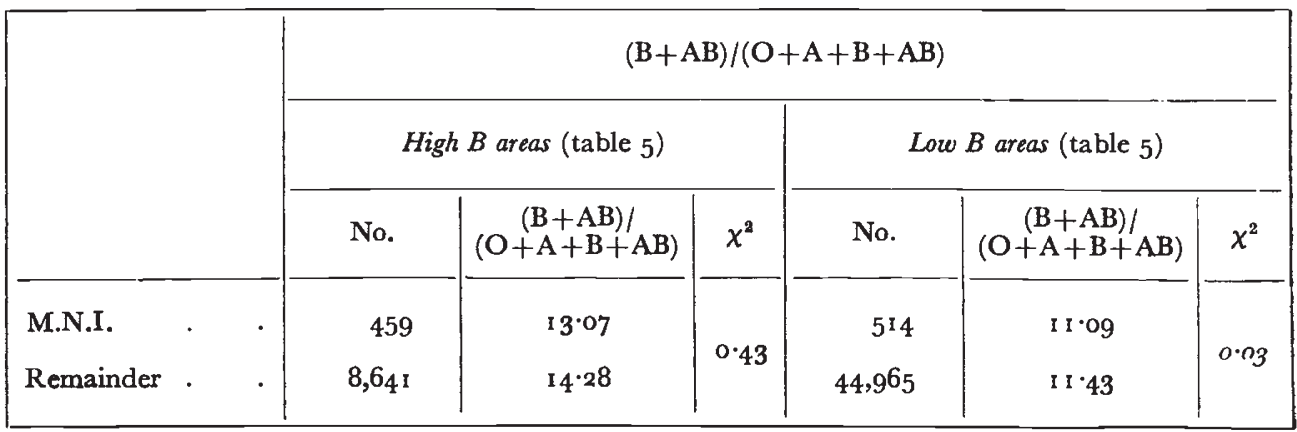

\section{(ii) A comparison of the sexes}

Some years ago, when the material from Yorkshire summarised in table 4 was being examined by Sir Ronald Fisher, he noted that at an unexpectedly large number of the centres there were proportionately more women $\mathrm{O}$ 's than men and more men A's than women. The difference of $0^{\circ} 5^{\mathrm{I}}$ per cent. in $\mathrm{A} /(\mathrm{O}+\mathrm{A})$ was significant. In a count based on the six south-western counties of England I found a somewhat larger difference, namely 0.90 per cent., which was highly significant. On the other hand a large and undoubtedly reliable sample obtained by Dr Janet Vaughan at Slough showed no such difference, the ratio being slightly, though non-significantly, higher in women. It was thought possible, however, that the discrepancy might be due to the constant influx into the London area from Scotland, Ireland, Wales and the North of immigrants with a lower percentage of $\mathrm{A}$ and a preponderance of men. These findings have been reported (Fisher and Roberts, 1943).

As shown in table 7 , the present material does not reveal any sex difference, the ratio $\mathrm{A} /(\mathrm{O}+\mathrm{A})$ being closely similar in the area taken as a whole, and in the area of high $\mathrm{O}$ and the area of low $\mathrm{O}$ taken separately. All differences are well below the level of significance. 
The sex of some 800 donors had not been recorded, half belonging to the Carlisle resigned panel, which, as is described in the next section, had to be reconstructed from the bleeding sheets. The 800 donors are omitted in the figures given in Table 7. Actually, all can be counted as men or all as women without affecting the conclusion.

TABLE 7

Comparison of the sexes in regard to the relative proportions of $O$ and $A$

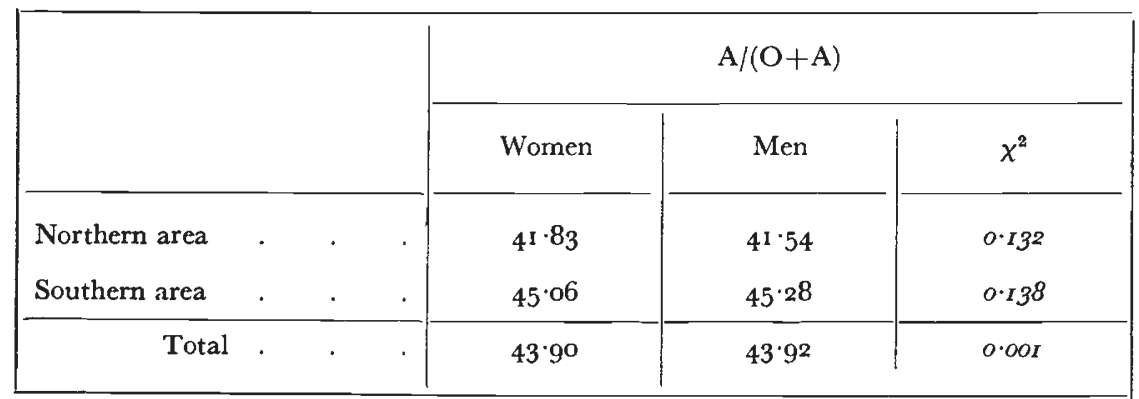

Note: The two areas here are nearly but not quite the same as Table 3 .

\section{SUMMARY}

1. A pilot survey has been carried out to throw light on :-

(a) The use that can be made for anthropological purposes of the records of the National Blood Transfusion Service.

(b) Any difficulties that might make their use unsafe in certain circumstances.

(c) Additional points of value that might be incorporated in future records.

(d) Methods of making the analysis economically.

(e) The extent to which local fluctuations in frequencies occur and hence the numbers and the detail that it is profitable to include, especially in densely populated areas.

2. The area selected was the Northern Region comprising the counties of Northumberland, Durham, Cumberland and Westmorland, with part of the North Riding of Yorkshire. So in addition to the points mentioned above, it was hoped that the survey would be of value as a detailed mapping of an interesting area.

3. In examining heterogeneity throughout the area two simple and basic $2 \times \mathrm{N}$ comparisons were used : the ratio $\mathrm{A} /(\mathrm{O}+\mathrm{A})$, which covers the largely reciprocal fluctuations of genes $\mathrm{O}$ and $\mathrm{A}$; the ratio $(B+A B) /(O+A+B+A B)$, which is closely related to the frequency of gene $\mathrm{B}$. For the first comparison areas must have a minimum number of donors of 20 ; for the second 70.

4. The geographical sub-division was made as fine as possible. Single towns, parts of towns and villages were kept separate when 
possible. The total count yielded 54,579 donors, divided into 321 areas, each containing at least 20 donors.

5. Both ratios showed highly significant heterogeneity. It was found that the original $3^{21}$ areas could be added together, purely geographically, to form larger aggregates up to a stage when there were $5^{2}$ areas, each containing at least 600 donors; at this stage, for both ratios, all the heterogeneity lay between the 52 areas and none within them. Further addition did not work, as at the next stage there was significant heterogeneity within areas. Accordingly the $5^{2}$ homogeneous areas were used for subsequent comparisons, though the group frequencies are given for the previous stage of 90 areas.

6. Fisher's test for the reasonableness of group proportions for the $5^{2}$ areas and for the total proved very satisfactory.

7. Nearly all the heterogeneity in the frequencies of genes $\mathrm{O}$ and $A$ is accounted for by the south-north rise in $O$ and fall in $A$. It is possible to draw a single line from east to west such that all the heterogeneity lies between the two areas so separated and none within them. The line passes through the middle of the densely populated Newcastle area.

8. The change is thus not a gradual one, but takes place at a definite line. A comparison with Fisher's figures for groups $\mathrm{O}$ and $\mathrm{A}$ in Yorkshire shows almost identical figures for the northern part of Yorkshire and the adjoining southern part of the region surveyed in this paper. In Yorkshire also the change in frequencies takes place at a very definite line, south of which the figures are very similar to those of southern England generally. It is likely that the northern half of the North of England Region is little different from Scotland, until the Highlands are reached.

9. The fluctuations in the frequency of gene B show exactly the opposite kind of variation. There is no general gradient, but very marked fluctuation from place to place, sometimes over relatively small distances.

Io. There is no indication of differences between rural and semirural areas and the towns they contain; nor is there any indication of social associations.

I I. There is no sex difference in frequencies.

I 2. Points that may help in the planning and carrying out of future surveys are discussed in the Appendix. Donors may not resign in proportion to their blood-groups and so it is very important that the records of all resigned donors should be complete and available. Unless this is certain, only new registrations can be counted. All the indications point to the present record being a satisfactory body of material. It is certainly worth while including in counts for the British Isles as large numbers as possible and making as fine a subdivision as possible, even within large towns. 


\section{APPENDIX}

\section{Some lessons on the making of counts from the records of the National Blood Transfusion Service}

r. In the practical business of establishing and maintaining a donor panel as the basis of a transfusion service, the point is soon reached when it becomes necessary to remove the cards of donors who are no longer active from the live panel which is in continual use. When donors die, or move away from the region, or resign, or fail to respond to repeated requests to attend for bleeding, their cards are removed and added to the resigned panel. It might be anticipated that the proportion of resignations is not necessarily the same in the different blood-groups. In earlier years particularly, donors of the different groups were called up with unequal frequency; and they may tend to resign if they are not called up often enough, or, alternatively, too often. A plan is needed for dealing with donors who fail to respond. In the North of England the practice has been that if a donor ignores three successive requests without writing or telephoning an explanation he or she is removed from the active panel and the card is added to the resigned panel. Thus if the frequency of calling up is different for different groups, defaulting donors of some groups will be removed in a shorter time than will those of others.

A comparison was made when the cards of the Transfusion Service panels for the four divisions of Newcastle had been copied, together with those of Gateshead. By this time some 5000 other donors had been included, drawn from centres in various parts of the region. This classification cuts across that of table 2, but will serve for the present purpose. The results are shown in table 8 . The live and

TABLE 8

Comparison of live and resigned panels, showing that each alone may give impossible frequencies, but that when added together the frequencies are unexceptionable

\begin{tabular}{|c|c|c|c|c|c|c|c|c|c|c|c|}
\hline & & \multirow{2}{*}{ No. } & \multicolumn{4}{|c|}{ Group frequencies per cent. } & \multicolumn{3}{|c|}{$\begin{array}{l}\text { Gene frequencies } \\
\text { per cent. }\end{array}$} & \multirow{2}{*}{$\begin{array}{c}\text { AB } \\
\text { Obs.- } \\
\text { Exp. }\end{array}$} & \multirow{2}{*}{$x^{2}$} \\
\hline & & & $\mathrm{O}$ & A & B & $\mathrm{AB}$ & $\mathrm{O}$ & A & B & & \\
\hline & & \multicolumn{8}{|c|}{ Four divisions of Newcastle and Gateshead } & & \\
\hline $\begin{array}{l}\text { Live } \\
\text { Resigned }\end{array}$ & . & $\begin{array}{l}5,727 \\
7,845\end{array}$ & $\begin{array}{l}4^{2} \cdot 68 \\
52 \cdot 95\end{array}$ & $\begin{array}{l}40 \cdot 39 \\
37 \cdot 58\end{array}$ & $\begin{array}{r}14 \cdot 07 \\
6 \cdot 56\end{array}$ & $\begin{array}{l}2 \cdot 86 \\
2 \cdot \operatorname{II}\end{array}$ & $\begin{array}{l}\ldots \\
\ldots\end{array}$ & $\begin{array}{l}\ldots \\
\ldots\end{array}$ & $\begin{array}{l}\cdots \\
\cdots\end{array}$ & $\begin{array}{r}-131 \cdot 83 \\
+74 \cdot 23\end{array}$ & $\begin{array}{l}39 \cdot 43 \\
26 \cdot 55\end{array}$ \\
\hline \multirow[t]{2}{*}{ Total } & . & 13,572 & $4^{8 \cdot 61}$ & $3^{8 \cdot 76}$ & $9 \cdot 73$ & $2 \cdot 89$ & $69 \cdot 6$ & $23 \cdot 7$ & $6 \cdot 7$ & $-37 \cdot 49$ & $2 \cdot 33$ \\
\hline & & \multicolumn{8}{|c|}{ Other areas counted up to that stage } & & \\
\hline $\begin{array}{l}\text { Live . } \\
\text { Resigned }\end{array}$ & . & $\begin{array}{l}3,169 \\
r, 786\end{array}$ & $\begin{array}{l}5^{I} \cdot 85 \\
54 \cdot 09\end{array}$ & $\begin{array}{l}36 \cdot 45 \\
34 \cdot 88\end{array}$ & $\begin{array}{l}9 \cdot 59 \\
8 \cdot 23\end{array}$ & $\begin{array}{l}2 \cdot \text { II } \\
2 \cdot 80\end{array}$ & $\begin{array}{l}\cdots \\
\cdots\end{array}$ & $\begin{array}{l}\ldots \\
\ldots\end{array}$ & $\begin{array}{l}\ldots \\
\ldots\end{array}$ & $\begin{array}{r}-21 \cdot 78 \\
+9 \cdot 93\end{array}$ & $\begin{array}{l}3 \cdot 9 I \\
I \cdot 84\end{array}$ \\
\hline Total & . & 4,955 & $52 \cdot 65$ & $35 \cdot 88$ & $9 \cdot 10$ & $2 \cdot 36$ & $72 \cdot 5$ & $21 \cdot 5$ & $6 \cdot 0$ & $-\mathrm{II} \cdot 49$ & $0 \cdot 76$ \\
\hline
\end{tabular}

resigned panels for Newcastle and Gateshead taken separately give entirely impossible group frequencies, whereas when they are added together the gene frequencies and the $\chi^{2}$ 's are perfectly reasonable. Although in the light of the points mentioned above, considerable discrepancies were not unexpected, their magnitude surprised the officers of the region, who do not feel that any suggested explanation is fully adequate. 
On the other hand the 5000 live and resigned donors from other areas do not differ greatly, though even amongst them the live panel gives a significant $\chi^{2}$. The difference from the Newcastle area may be due to the fact that donors on the smaller panels making up the 5000 were called for bleeding without the same degree of selection. With a small panel it was necessary to call all the donors, of whatever group, on each occasion in order to ensure an economic session. But even if there may not always be a serious difference, or indeed any difference, between live and resigned panels, this cannot be guaranteed without making a count of both.

The completeness of the resigned panel is thus the most important factor in determining whether or not the records of the past can be used with safety. If there is any possibility that some of the cards of resigned donors may have been destroyed, the whole record is unusable for anthropological purposes. And it is not only a question of destruction. The cards of resigned donors may be stored in a way that makes it possible for some of them to be overlooked when a count is attempted. Only if it is reasonably certain that the whole record, live and resigned, is complete, can any existing body of data be used for analysis. Failing this the only plan is to fix a date and count new registrations from that time onwards.

The whole body of data from the Northern Region shows, as it was hoped would be the case, every indication of completeness, but at one centre, Carlisle, it was found that the resigned cards had been destroyed. Sooner than omit this important area and so spoil the completeness of the analysis for the Region as a whole, it was decided to reconstruct the resigned panel from the original bleeding sheets, that is, the detailed records of all donations of blood, these still being available. It naturally proved to be a most troublesome and time-consuming task, not to be recommended for any purpose other than the filling in of a gap, as in this instance. It was necessary to prepare a card index from all the bleeding sheets, as well as of the live panel, going back to the beginnings of the Service, and then to attempt to eliminate duplicates. The magnitude of the work will be realised when it is mentioned that the original index (with many duplicates eliminated as the work proceeded) amounted to 8000 cards. The difficulties due to similar common names, marriage, change of address and so forth will be obvious enough. During the last stages Mr C. H. Holland, the Regional Donor Officer, gave his help and I trust that the final index of resigned donors contains relatively few donors counted twice or instances of two separate donors considered to be the same person. There is a check on the second possibility. No attention was paid to blood-group in making the decision and when the original 8000 had been reduced to a quarter of that number it was found that in only 8 instances were the groups different in donors supposed to be the same. The first source of error, that is, counting a single donor twice, cannot be directly checked, but I hope that it too has led to little inaccuracy. The Carlisle figures taken as a whole, and broken down in different ways, revealed no suspicious anomaly, so for the sake of completeness they are included, in the hope, which I trust is not unreasonable, that no appreciable error has been introduced.

2. The borrowing of the original cards for copying is to be avoided. The present pilot survey was only made possible by the willingness of the Region to lend them ; but it put the officers to a great deal of trouble. At the receiving end, batches of live cards had to be dealt with very quickly at times and there was always anxiety lest some of the cards, which were irreplaceable, might go astray. A count based on the accumulated material of the past is very difficult to carry out except by someone working locally and preferably someone in the Transfusion Service.

The ideal plan, which it is hoped will now be operated for newly registered donors, involves the preparation of copies by the Regions at the time of registration for transmission to and retention by the Nuffield Blood Group Centre at the Royal Anthropological Institute. 
3. The breaking-down of the material by geographical area was the most difficult and time-consuming part of the present enquiry. To do so ad hoc for every fresh survey is clearly not to be recommended. The only indication of area on the cards is postal address so this must be accepted as the basis of classification. What is required is a code made once and for all, so that any address can be immediately turned into a code number. The code must be hierarchical, so that a count can be made at any desired level of sub-division. The best plan would then be to code fully in the first place down to the finest sub-division provided and to prepare the tables (or better, summary cards) accordingly. Coarser grouping could then be made by addition. The code should be based on numbers of people rather than on square miles, which is presumably what postal address essentially does. The postal districts of large cities should be adequate for tracing possible variations within them. Coding in this way should reduce the work to a minimum and make it possible to add new counts to previous ones.

4. In the present survey the use of punched card methods was a great convenience. The cards had to be copied anyway and punching and verification, using an electric automatic key punch, was quicker than hand copying would have been. The ultimate sorting and counting was carried out very conveniently on Powers-Samas sorter-counters and it might be mentioned that there was never any trouble about exact agreement of totals and sub-totals. Nor was any card wrecked su badly that the information could not be reconstituted and a new card punched. The punching and verification was carried out by my assistants, Miss Hill and Miss Ralph, and the Powers-Samas company kindly allowed us to take batches of cards to their Office to put through a comparator, so avoiding the necessity for sight reading of the verification. The sorting and counting was also done by ourselves, and it should be added that the scheme was workable only because we had the machines, both automatic punch and sorter-counters, available at the School of Hygiene.

Nevertheless, I am doubtful whether punched card methods are needed when copies of the original cards are provided and can be retained. Once the area code number has been entered, the copies can be hand sorted and counted as desired and tables or summary cards prepared once and for all, without it being necessary to repeat the copying process. This would cover the ordinary routine count, which involves so few and such simple particulars ; though for special pieces of work, for example, an analysis using family names, punched card methods might be considered.

5. If one considers that much of the present variation in blood-group frequencies is probably a diluted version of the variation that once existed, then anything that can push the count backwards in time, as it were, should be of value. One way of doing this is to record place of birth as well as present residence. Place of birth of father and of mother is an additional refinement. It is not suggested, however, that these particulars should replace present residence as the basis of the count ; rather, they should be used for alternative counts, because the place of birth of the donor and still more of father and mother will often not be specified with the accuracy needed for fine geographical sub-division.

Classification by family name, as a partial measure of racial origin, has proved useful in many surveys and will probably do so in this one. Here a refinement is to record the maiden name of married women and the maiden name of mother. Once again, however, I think that I should state my personal opinion that basic counts should refer to all donors in each area, except for readily identifiable large bodies of clearly temporary and non-local residents, such as military personnel at a camp. The refinements add greatly to the value of surveys and the results may be largely discussed in terms of them; but it is the total basic counts that will be most easily comparable over periods of time and sometimes as between area and area when different workers are concerned.

During the course of the work there have been discussions with the authorities of the National Blood Transfusion Service on the possibility of adding items of 
information of anthropological value. As a result certain additional particulars have already been incorporated in the record cards.

6. It is evident that for the present at least it will be profitable to analyse material from all over the country, using as large numbers as are available and with as fine a geographical sub-division as is practicable. It is impossible to say without trying it what other large towns may not show the heterogeneity of the Newcastle area; only when it is established that no such variation exists should the count be stopped or the sub-division made coarser. If the evidence is reviewed from time to time it will become clear when in any part of the country addition to existing counts is unlikely to yield much further information; but that time is not yet. There is still much work to do in filling in the details of the ABO maps of the British Isles, to say nothing of the other blood-group systems. This will not only give the general picture, but will help to indicate particular areas where more intensive work would be profitable. Special investigations can then be planned, using numbers much larger than those even of the Transfusion Service and incorporating additional information that cannot be obtained from donors' record cards.

Acknowledgments.-The investigation was made possible by a grant from the Nuffield Foundation. I am greatly indebted to the colleagues who have been associated with me in the planning of this pilot survey: Dr C. D. Darlington, the prime mover; Dr W. d'A Maycock; Dr A. E. Mourant ; and Dr R. R. Race. Admirable arrangements were made by the North of England Region of the National Blood Transfusion Service and I wish to record my great indebtedness to the officers : $\operatorname{Dr}$ T. H. Boon, the Regional Director ; and later his successor, Dr S. M. C. Murray ; Mr C. H. Holland, the Regional Donor Officer. Much preliminary planning was needed in order to produce a workable procedure and thereafter Mr Holland and his staff went to great trouble in preparing batches of cards to send to us and in continual checking to see that all were duly sent. Miss P. McCracken worked out a special sub-division of the Sunderland area, which will be used in a subsequent paper. Mr Holland has taken a keen personal interest throughout and his advice and help in explaining the material and the Region and in resolving many queries and difficulties have been quite invaluable. I am also greatly indebted to Miss L. Hill, who was appointed for a period to help with the copying and analysis, and to my assistant, Miss M. D. Ralph, for their patient and accurate work. I am indebted to Mrs M. G. Young for drawing the maps.

\section{REFERENCES}

BELLOC, H. 1912. Warfare in England. London: Williams and Norgate.

DOBson, A. M., AND IKIN, E. W. 1946. The ABO blood-groups in the United Kingdom; frequencies based on a very large sample. 7. Path. Bact., $58,221-227$. FISHER, R. A., AND ROBERTS, J. A. F. 1943. A sex difference in blood-group frequencies. Nature, Lond., ${ }_{15} 1,640$.

FISHER, R. A., AND TAYLOR, G. L. I940. Scandinavian influence in Scottish ethnology. Nature, Lond., 145, 590.

MOURANT, A. E., AND WATKIN, I. M. 1952. Blood-groups, anthropology and language in Wales and the western counties. Heredity, 6, 1 3-36.

RoBerts, J. A. F. I $94^{8}$. The frequencies of the ABO blood-groups in south-western England. Annals of Eugenics, 14, I O9-1 16.

Watkin, I. M. I 95 r. Geographical Genetics of the Welsh People. Ph.D. Thesis, University of London. 